GRASAS Y ACEITES 65 (2)

April-June 2014, e027

ISSN-L: 0017-3495

doi: http://dx.doi.org/10.3989/gya.109813

\title{
Characterization of apple seed oil with Denomination of Origin from Asturias, Spain
}

\author{
J.C. Bada ${ }^{\mathrm{a}}$, M. León-Camacho ${ }^{\mathrm{b}}$, P. Copovi ${ }^{\mathrm{a}}$ and L. Alonso ${ }^{\mathrm{a}, \mathbb{}}$ \\ ${ }^{a}$ Instituto de Productos Lácteos de Asturias (CSIC). Paseo Rio Linares s/n. 33300 Villaviciosa-Asturias, Spain \\ ${ }^{\mathrm{b}}$ Instituto de la Grasa (CSIC), Avda Padre García Tejero 4, 41012 Sevilla, Spain \\ Corresponding author: lalonso@ipla.csic.es
}

Submitted: 25 October 2013; Accepted: 17 January 2014

SUMMARY: The content and composition of lipids isolated from the seeds of seven apple species from Asturias (Spain) were characterized. The highest content in oil corresponded to Collao $\left(22.73 \pm 0.81 \mathrm{~g} \cdot 100 \mathrm{~g}^{-1}\right.$ of seed), followed by Raxao and Riega $\left(20.19 \pm 0.74 \mathrm{~g} \cdot 100 \mathrm{~g}^{-1}\right.$ of seed; $19.67 \pm 0.85 \mathrm{~g} \cdot 100 \mathrm{~g}^{-1}$ of seed), respectively. The linoleic acid was found to be the main component in Limón Montés $(60.78 \pm 3.07 \%)$ followed by Riega $(60.01 \pm 3.41 \%)$. Solarina seed oil was the one with the highest content in total sterols $\left(558.52 \pm 9.42 \mathrm{mg} \cdot 100 \mathrm{~g}^{-1}\right.$ of oil) while Blanquina was the one that presents the lowest amount $\left(166.55 \pm 1.89 \mathrm{mg} \cdot 100 \mathrm{~g}^{-1}\right.$ of oil). Phosphatidylcholine $(70.58 \pm 3.85 \%)$ was found to be the main constituent in Blanquina followed by Collaos $(55.55 \pm 2.96 \%)$. Raxao presented the highest content in $\beta$-tocopherol (125.29 \pm 12.62$)$ and $\alpha$-tocopherol was the most important tocopherol in Limón Montés $\left(84.68 \pm 5.61 \mathrm{mg} \cdot \mathrm{kg}^{-1}\right.$ of oil). The main triglycerides were LLP $(41.17 \pm 1.98-39.32 \pm 1.66 \%)$ followed by LLL $(27.12 \pm 1.32-17.80 \pm 1.96 \%)$. Good separation among specie samples according to the statistical analysis of the principal component (PCs) and linear discriminant analysis (LDA) was obtained.

KEYWORDS: Apple; Fatty acids; Oils; Phospholipids; Sterols; Tocopherols; Triglycerides

RESUMEN: Caracterización de aceite de semilla de manzanas con Denominación de Origen de Asturias, España. Se ha caracterizado el contenido y composición de los lípidos aislados de semillas de siete especies de manzanas de Asturias (España). El contenido más alto en aceite correspondió a Collao $\left(22.73 \pm 0.81 \mathrm{~g} \cdot 100 \mathrm{~g}^{-1} \mathrm{de}\right.$ semilla), seguida de Raxao y Riega $\left(20.19 \pm 0.74 \mathrm{~g} \cdot 100 \mathrm{~g}^{-1}\right.$ de semilla y $19.67 \pm 0.85 \mathrm{~g} \cdot 100 \mathrm{~g}^{-1}$ de semilla) respectivamente. El ácido linoleico fué el de mayor contenido en Limón Montés $(60.78 \pm 3.07 \%)$ seguido por la Riega (60.01 $\pm 3.41 \%)$. El contenido más alto en esteroles correspondió a Solarina $\left(558.52 \pm 9.42 \mathrm{mg} \cdot 100 \mathrm{~g}^{-1} \mathrm{de}\right.$ aceite) mientras que Blanquina fué el que presentó los valores más bajo (166.55 $\pm 1.89 \mathrm{mg} \cdot 100 \mathrm{~g}^{-1}$ de aceite). Fosfatidilcolina $(70.58 \pm 3.85 \%$ del total FL) fué el principal constituyente en Blanquina seguida por Collao $\left(55.55 \pm 2.96 \%\right.$ del total FL). Raxao presentó el contenido más alto en $\beta$-tocoferol $\left(125.29 \pm 12.62 \mathrm{mg} \cdot \mathrm{Kg}^{-1} \mathrm{de}\right.$ aceite) y $\alpha$-tocoferol en Limón Montés $\left(84.68 \pm 5.61 \mathrm{mg} \cdot \mathrm{Kg}^{-1}\right.$ de aceite). Los triglicéridos principales fueron LLP (41.17 $\pm 1.98-39.32 \pm 1.66 \%)$ seguido de LLL $(27.12 \pm 1.32-17.80 \pm 1.96 \%)$. Se obtuvo una buena separación entre las distintas variedades de manzana teniendo en cuenta el análisis estadístico de los principales componentes (PCs) y el análisis discriminante linear (LDA).

PALABRAS CLAVE: Aceites; Ácidos grasos; Esteroles; Fosfolípidos; Manzana; Semilla; Tocoferoles; Triglicéridos

Citation/Cómo citar este artículo: Bada JC, León-Camacho M, Copovi P, Alonso L. 2014. Characterization of apple seed oil with Denomination of Origin from Asturias, Spain. Grasas Aceites 65 (2): e027. doi: http://dx.doi.org/10.3989/ gya.109813.

Copyright: (C) 2014 CSIC. This is an open-access article distributed under the terms of the Creative Commons Attribution-Non Commercial (by-nc) Spain 3.0 Licence. 


\section{INTRODUCTION}

In the last few years, there has been a considerable interest in finding new food sources that will meet the health and nutritional needs of the world's population (Maazouzi et al., 2007; Ohama et al., 2006; Yukui et al., 2009). In Japan, many of the new foods with health claims have been wild vegetables (Cai et al., 2003), such as mustard leaf (Liang et al., 2006) and elm fruit (Hu et al., 2006). Such resources are limited, and more attention should be paid to existing waste resources such as apple seed oils. Denomination of origin (DO) is a special consideration for some foods and drinks to recognize that they have benefits and particular characteristics in many differentiated geographical areas, and the influence of human factor in their production (European Union, 2008). Spain is one of the most important countries of the European Union for the production of cider, producing about 585,000 tons of apples as fruit for human consumption and 75,000 tons of apples to make cider. Asturias is the region with the most important cultivation of apples for the production of cider and have 22 apple varieties included in the DO. Cider, in general, is produced with different varieties of apples, but the cider with DO from Asturias is produced only with apples recognized by the DO (BOE, 2003). In the process for producing cider, there are two important by-products, seeds and skins. The seeds have variable contents in oils. In the cider industry, this seed is not used for producing apple seed oil, and it is a waste product. Fruit seed oil has been widely applied in food, perfumes, toiletries and chemical additives (Stone and Kushner, 2000; Etherton and Etherton, 2003). Plant seed oil is one of the most interesting essential oils due to its properties (Anwar et al., 2006; Lei Tian et al., 2010). A few authors have published papers about apple seed oil and they describe some of its properties (Yu et al., 2007; Yukui et al., 2009; Lei Tian et al., 2010).

The aim of this research was to study the oils of seven different apple seed oils from Asturias (Spain), Blanquina, Raxao, Collaos, Durona, Riega, Solarina and Limón Montés species pertaining to the DO cider from Asturias. The composition in fatty acids, sterols, phospholipids, tocopherols and triglycerides were characterized, as well as the total contents in oil and moisture.

\section{MATERIAL AND METHODS}

\subsection{Samples}

The apple seed species (Table 1) used in the present study came from different plantations in the region of Asturias (Spain), Serida (Principado de Asturias) and San Martín-Llanes (Asturias) collected during a period of suitable ripening. Once prepared at room temperature, the solid matter (skin and pulp) was separated from the seeds.

\subsection{Solvent oil extraction and water content}

Samples were blanched and ground in an electrical grinder. The oil was extracted in a Soxhlet glass apparatus using hexane as solvent (IUPAC, 1987a). Moisture was determined by weight loss after heating in an oven at $105{ }^{\circ} \mathrm{C}$ in accordance with (IUPAC, 1987b).

\subsection{Fatty acid analysis}

Fatty acid methyl-esters (FAME) were analyzed by gas chromatography (GC). FAME were extracted with n-heptane after cold methylation with $2 \mathrm{~N} \mathrm{KOH}$ in methanol (IUPAC, 1987c). FAME analysis was performed on an HP-5890-II apparatus (HewlettPackard, Palo Alto, CA) using a fused silica capillary SP-2380 column $(60 \mathrm{~m} \times 0.25 \mathrm{~mm}, 0.2 \mu \mathrm{m}$ film thickness) with a flame ionization detector (FID). The oven temperature was kept at $160{ }^{\circ} \mathrm{C}$ for $13 \mathrm{~min}$ and was then raised to $190^{\circ} \mathrm{C}$ at a rate of $1.5^{\circ} \mathrm{C} \mathrm{min}^{-1}$ and held isothermally for $20 \mathrm{~min}$. The injector temperature was kept at $225^{\circ} \mathrm{C}$, while the detector temperature was $250^{\circ} \mathrm{C}$. Hydrogen (19 psi inlet pressure) was used as carrier gas, while the make-up gas was nitrogen. Standards of each fatty acid were used to identify the fatty acids. These were purchased from Sigma-Aldrich (St. Louis, MO): palmitic $(\mathrm{P}=\mathrm{C} 16: 0)$, palmitoleic $(\mathrm{Po}=\mathrm{C} 16: 1)$, stearic $(\mathrm{S}=\mathrm{C} 18: 0)$, oleic $(\mathrm{O}=\mathrm{C} 18: 1 \omega 9$ cis), linoleic ( $\mathrm{L}=\mathrm{C} 18: 2)$ alpha and gamma, linolenic $(\mathrm{Lo}=\mathrm{C} 18: 3)$. Fatty acids were identified in the samples by comparing the retention times for standards and those of the samples. The area was expressed as percentages of areas of the total fatty acids.

\subsection{Sterol analysis}

The unsaponifiable fraction was extracted as described (European Communities 1991). $0.5 \mathrm{~mL}$ 5 - $\alpha$-cholestanol (Fluka, Buchs, Switzerland) solution in chloroform was added to $5 \mathrm{~g}$ of oil as an internal standard. The mixture was saponified for 0.5 hour with $50 \mathrm{~mL}$ of $2 \mathrm{~N}$ ethanolic potassium hydroxide. The solution was then passed to a $500 \mathrm{~mL}$ decanting funnel, $100 \mathrm{~mL}$ distilled water were added and the mixture was extracted twice with three $80 \mathrm{~mL}$ portions of diethyl ether. The diethyl ether extracts were combined in another funnel and were washed several times with $100 \mathrm{~mL}$ portions of water, until the wash reached a neutral $\mathrm{pH}$. The diethyl ether solution was dried over anhydrous sodium sulphate and evaporated to dryness in a rotary evaporator at $30^{\circ} \mathrm{C}$ under reduced pressure. After purification by thinlayer chromatography (IUPAC, 1987d), the sterol fraction was analyzed and quantified by gas chromatography in an HP 5890-II apparatus equipped with a 
TABLE 1. Oil ( $\mathrm{g} \cdot 100 \mathrm{~g}^{-1}$ seed), moisture $\left(\mathrm{g} \cdot 100 \mathrm{~g}^{-1}\right.$ seed) and seed yield $\left(\mathrm{g} \cdot 10 \mathrm{Kg}^{-1}\right.$ fruit) from the different varieties of apples

\begin{tabular}{lllccc}
\hline Cultivar & \multicolumn{1}{c}{ Variety } & Fruit $(\mathbf{k g})$ & Seed yield $(\mathbf{g})$ & Oil $(\mathbf{\%})$ & Moisture $(\%)$ \\
\hline A & Blanquina & $10 \pm 0.13$ & $5.19 \pm 0.23^{*}$ & $18.82 \pm 0.62$ & $9.26 \pm 0.12$ \\
B & Raxao & $10 \pm 0.19$ & $4.76 \pm 0.32^{*}$ & $20.19 \pm 0.74$ & $8.79 \pm 0.18^{*}$ \\
C & Collaos & $10 \pm 0.14$ & $5.56 \pm 0.19$ & $22.73 \pm 0.81$ & $8.19 \pm 0.13^{*}$ \\
D & Durona & $10 \pm 0.16$ & $4.56 \pm 0.16^{*}$ & $17.71 \pm 0.65$ & $8.53 \pm 0.11$ \\
E & Riega & $10 \pm 0.12$ & $6.43 \pm 0.19$ & $19.67 \pm 0.85$ & $7.62 \pm 0.10$ \\
F & Solarina & $10 \pm 0.14$ & $7.21 \pm 0.17^{*}$ & $16.87 \pm 0.61^{*}$ & $8.12 \pm 0.13$ \\
G & Limón Montés & $10 \pm 0.18$ & $7.49 \pm 0.21$ & $18.67 \pm 0.66^{*}$ & $7.13 \pm 0.12^{*}$ \\
\hline
\end{tabular}

Mean standard deviation $(\mathrm{n}=3)$.

$* P \leq 0.001$.

split-splitless injector and a flame ionization detector. An HP-5 fused silica capillary column $(30 \mathrm{~m} \times 0.32$ $\mathrm{mm}$ i.d., $0.25 \mathrm{~mm}$ film thickness) was used with hydrogen (7 psi inlet pressure) as the carrier gas and nitrogen the make-up gas. The oven temperature was maintained isothermally at $265{ }^{\circ} \mathrm{C}$ for $30 \mathrm{~min}$. The injector temperature was $280{ }^{\circ} \mathrm{C}$, while the detector was kept at $300^{\circ} \mathrm{C}$. Previously, the sterol fraction was derivatized as trimethylsilyl ethers (TMS) according to the method proposed in (European Communities, 1991). The sterols were identified by comparison of the mass spectral data with those of authentic reference compounds and by comparing their retention times with sterols from olive, sunflower and soybean oils (León-Camacho and Morales, 2000).

\subsection{Phospholipid and triglyceride analysis}

Phospholipids were analyzed by reverse phase analysis of the lipids carried out on a Water Acquity Ultra Performance LC (UPLC) system using an Acquity UPLC-Bech C18 column $(2.1 \times 10 \mathrm{~mm}$, $1.5 \mu \mathrm{m})$ at $40{ }^{\circ} \mathrm{C}$. The solvent consisted of water/ methanol (10/90) and the flow rate of $1 \mathrm{~mL} \mathrm{~min}^{-1}$, which was coupled to an evaporating light scattering detector (ELSD 2424-Waters). As the nebulizing gas, $\mathrm{N}_{2}$ was used at a flow rate of $1.4 \mathrm{~L} \mathrm{~min}^{-1}$, and a nebulizing temperature of $80^{\circ} \mathrm{C}$. The injection volume was $10 \mu \mathrm{L}\left(30 \mathrm{mg} 10 \mathrm{~mL}^{-1}\right.$ oil sample). The assignment of chromatographic peaks was carried out by means of standards purchased from Sigma-Aldrich (St.Louis, MO). Tryglycerides were performed on a capillary gas chromatography column $(25 \times 0.25$ $\mathrm{mm}$ ) coated with TAB-CB in an HP 5890-II apparatus equipped with a split-splitless injector and a flame ionization detector (Chrompack) according to the procedure described by Alonso, 1993.

\subsection{Tocopherol analysis}

Tocopherols were quantified by high performance liquid chromatography (HPLC). The HPLC system consisted of a low pressure quaternary pump
HP-1050, a Rheodyne injection valve (20 mL loop), a thermostatic furnace and a fluorescence detector RF-235 (Shimadzu, Kyoto, Japan). Separation was performed in a $250 \times 4 \mathrm{~mm}$ particle size $5 \mu \mathrm{m}$ Lichrospher Si-60 (Merck, Darmstadt, Germany) column. The column and detector were kept at a temperature of $40{ }^{\circ} \mathrm{C}$. The mobile phase was n-hexane/2propanol 99/1 (v/v). The flow rate was supported at

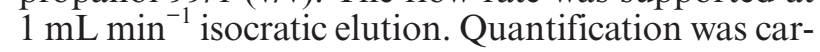
ried out by a calibration system based on standards (IUPAC, 1987d).

\subsection{Statistical analysis}

In order to determine significant differences among species, the main effects analysis of variance (ANOVA) was performed according to the general lineal model procedure. The data were analyzed using the statistical package CSS: Statistica 8.0 software (StatSoft Inc., 1995). The compounds identified were considered as chemical descriptors. A data matrix was built where rows are the samples and columns are the variables. Each element of this matrix, expressed as xij, corresponds to the content of compound $\mathrm{j}$ for the sample $\mathrm{i}$. In order to obtain a better understanding of the data trends, pattern recognition methods such as principal component analysis (PCA) and linear discrimination analysis (LDA) were applied.

\section{RESULTS AND DISCUSION}

\subsection{Oil composition analysis}

Table 1 shows the content in oil, moisture and seed yield for Blanquina, Raxao, Collaos, Durona, Riega, Solarina and Limón Montés apple seeds. The highest oil content corresponded to Collao

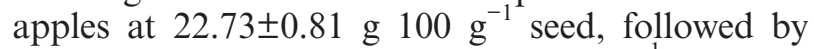

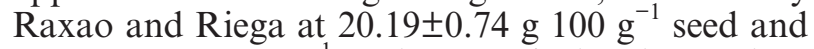

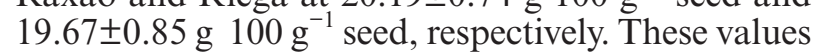
are slightly higher than those reported by Tian et al. (2010) in a study of antioxidant and antimicrobial 
TABLE 2. Fatty acid composition (\%) of lipid fractions extracted from apple seed oils

\begin{tabular}{lllllllllc}
\hline Cultivar & \multicolumn{1}{c}{ C16:0 } & \multicolumn{1}{c}{ C16:1 } & \multicolumn{1}{c}{ C18:0 } & C18:1 & C18:2 & C18:3 & C20:0 & C20:1 & C22:0 \\
\hline A & $8.49 \pm 0.98$ & $0.08 \pm 0.01 *$ & $1.90 \pm 0.13$ & $32.71 \pm 2.65$ & $53.98 \pm 3.16$ & $0.30 \pm 0.06$ & $1.53 \pm 0.19$ & $0.51 \pm 0.08$ & $0.28 \pm 0.03$ \\
B & $8.67 \pm 0.67$ & $0.08 \pm 0.01$ & $1.98 \pm 0.11$ & $30.53 \pm 1.98$ & $56.31 \pm 3.25$ & $0.25 \pm 0.05$ & $1.34 \pm 0.11$ & $0.40 \pm 0.07$ & $0.25 \pm 0.02$ \\
C & $8.07 \pm 0.71 *$ & $0.07 \pm 0.02$ & $2.30 \pm 0.15^{*}$ & $36.57 \pm 2.08$ & $50.34 \pm 2.91$ & $0.25 \pm 0.04 *$ & $1.48 \pm 1.15$ & $0.45 \pm 0.09$ & $0.25 \pm 0.04$ \\
D & $8.28 \pm 0.84$ & $0.08 \pm 0.01$ & $1.90 \pm 0.18$ & $34.32 \pm 2.15$ & $52.97 \pm 3.29$ & $0.28 \pm 0.06$ & $1.27 \pm 0.09$ & $0.48 \pm 0.08$ & $0.25 \pm 0.03$ \\
E & $9.18 \pm 0.92^{*}$ & $0.12 \pm 0.03$ & $1.75 \pm 0.12^{*}$ & $27.02 \pm 1.69$ & $60.01 \pm 3.41$ & $0.34 \pm 0.06$ & $1.14 \pm 0.12^{*}$ & $0.36 \pm 0.06$ & $0.17 \pm 0.02$ \\
F & $9.01 \pm 0.85$ & $0.09 \pm 0.02$ & $1.97 \pm 0.13$ & $31.85 \pm 2.07$ & $54.49 \pm 2.91$ & $0.40 \pm 0.04 *$ & $1.28 \pm 1.11$ & $0.46 \pm 0.08$ & $0.23 \pm 0.03$ \\
G & $8.89 \pm 0.93^{*}$ & $0.12 \pm 0.02^{*}$ & $1.75 \pm 0.12^{*}$ & $27.02 \pm 1.91$ & $60.01 \pm 3.07$ & $0.34 \pm 0.03$ & $1.14 \pm 0.13$ & $0.36 \pm 0.07$ & $0.17 \pm 0.02$ \\
\hline
\end{tabular}

Mean standard deviation $(\mathrm{n}=3)$.

$* P \leq 0.001$.

activities of the oil in apple seeds. The moisture contents ranged between $7.13 \pm 0.12{\mathrm{~g} 100 \mathrm{~g}^{-1} \text { seed }}^{-1}$

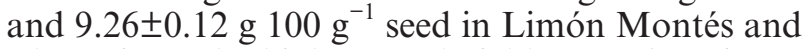
Blanquina. The highest seed yields were for Limón Montés $\left(7.49 \pm 0.21 \mathrm{~g}\right.$ of seed $10 \mathrm{Kg}^{-1}$ of fruit) and Solarina $\left(7.21 \pm 0.17 \mathrm{~g}\right.$ of seed $10 \mathrm{Kg}^{-1}$ of fruit). Table 2 shows the fatty acid compositions of the apple seed oil. Linoleic acid was found to be the main component in the oil of the Limón Montés species

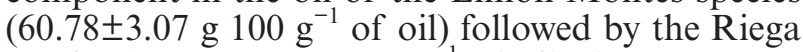

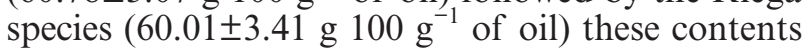

are higher than those found by other authors (Yukui et al., 2009; Tian et al., 2010). The highest concen-

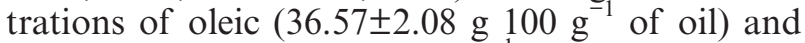

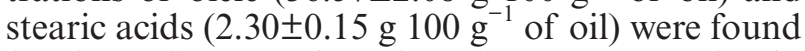
for the Collaos species. These data are somewhat in agreement with those found by $\mathrm{Yu}$ et al. (2007) in a study of the proximate composition of the apple seed and the characterization of its oil. Almost all phospholipid (PL) classes were identified in the phospholipid fraction (Table 3). Phosphatidylcholine $(70.58 \pm 3.85 \%$ of the total PL) was found to be the

TABLE 3. Phospholipid ( $\%$ of total PL) compositions from apple seed oils

\begin{tabular}{lccccc}
\hline Cultivar & Total PL & LPC & PC & PE & PI \\
\hline A & $0.38 \pm 0.06$ & $3.75 \pm 0.31$ & $70.58 \pm 3.85$ & $8.71 \pm 0.52^{*}$ & $17.16 \pm 0.21^{*}$ \\
B & $0.45 \pm 0.08$ & $4.88 \pm 0.39$ & $35.78 \pm 0.31^{*}$ & $27.53 \pm 0.22$ & $31.80 \pm 0.25$ \\
C & $0.41 \pm 0.06$ & $5.18 \pm 0.57$ & $55.55 \pm 2.96$ & $16.95 \pm 1.52^{*}$ & $22.32 \pm 1.91$ \\
E & $0.52 \pm 0.07$ & $3.10 \pm 0.27^{*}$ & $40.65 \pm 2.61$ & $31.39 \pm 1.69$ & $24.85 \pm 1.51$ \\
F & $0.49 \pm 0.08$ & $3.01 \pm 0.19^{*}$ & $42.59 \pm 2.85$ & $30.80 \pm 1.54$ & $23.59 \pm 1.32$ \\
\hline
\end{tabular}

Men standard deviation $(\mathrm{n}=3)$.

$* P \leq 0.001$.

LPC: Lisophosphatidilcolina; PC: Phosphatidilcolina; PE: Phosphatidylethanolamina; PI: Phosphatidylinositol.

TABLE 4. Total sterol (mg $100 \mathrm{~g}^{-1}$ of oil) of lipid fractions extracted from apple seed oils

\begin{tabular}{|c|c|c|c|c|c|c|c|c|c|}
\hline Cultivar & Cholesterol & Campesterol & Stigmasterol & Chlerosterol & $\beta$-Sitosterol & Sitostanol & $\begin{array}{c}\Delta 5- \\
\text { Avenasterol }\end{array}$ & $\begin{array}{c}\Delta 5,24- \\
\text { Stigmastadienol }\end{array}$ & $\begin{array}{c}\Delta 7- \\
\text { Stigmastenol }\end{array}$ \\
\hline A & $1.39 \pm 8.22$ & $17.70 \pm 0.22$ & $1.61 \pm 0.12$ & $1.26 \pm 0.02$ & $166.55 \pm 1.89$ & $5.21 \pm 0.16$ & $14.37 \pm 0.43$ & $1.31 \pm 0.12$ & $9.85 \pm 1.17$ \\
\hline B & $3.03 \pm 2.80$ & $28.16 \pm 0.75$ & $1.78 \pm 0.21$ & $1.76 \pm 0.10$ & $225.13 \pm 1.89$ & $1.34 \pm 0.25$ & $20.05 \pm 0.20$ & $2.05 \pm 0.22$ & $5.05 \pm 1.53^{*}$ \\
\hline $\mathrm{C}$ & $2.94 \pm 2.39$ & $22.94 \pm 1.78$ & $1.58 \pm 0.31$ & $1.52 \pm 0.39$ & $231.6 \pm 12.39$ & $7.9 \pm 0.39$ & $22.69 \pm 1.40$ & $2.43 \pm 0.79$ & $26.65 \pm 2.75$ \\
\hline $\mathrm{D}$ & $1.74 \pm 8.19$ & $21.93 \pm 0.65$ & $1.98 \pm 0.23$ & $1.86 \pm 0.28$ & $254.04 \pm 7.64$ & $1.93 \pm 0.89 *$ & $14.42 \pm 1.11$ & $6.29 \pm 0.70^{*}$ & $32.22 \pm 2.04$ \\
\hline $\mathrm{E}$ & $2.40 \pm 0.16$ & $39.76 \pm 0.62$ & $3.19 \pm 0.29$ & $1.66 \pm 0.05$ & $392.48 \pm 8.92$ & $21.58 \pm 0.69$ & $28.35 \pm 1.19$ & $2.42 \pm 0.27$ & $67.51 \pm 2.93$ \\
\hline $\mathrm{F}$ & $2.97 \pm 0.24$ & $48.63 \pm 2.52$ & $4.05 \pm 0.37 *$ & $2.44 \pm 0.15$ & $558.52 \pm 9.42 *$ & $40.64 \pm 0.86$ & $56.59 \pm 1.94$ & $4.94 \pm 0.63$ & $103.70 \pm 2.13$ \\
\hline G & $2.64 \pm 0.29$ & $49.25 \pm 1.16$ & $2.56 \pm 0.21$ & $2.06 \pm 0.45$ & $410.75 \pm 5.34$ & $13.30 \pm 0.62$ & $31.22 \pm 1.12$ & $1.97 \pm 0.45$ & $30.00 \pm 2.74$ \\
\hline
\end{tabular}

Mean standard deviation $(\mathrm{n}=3)$.

${ }^{*} P \leq 0.001$. 
TABLE 5. Tocopherol contents ( $\mathrm{mg} \cdot \mathrm{Kg}^{-1}$ of oil) of lipid fractions extracted from apple seed oil samples

\begin{tabular}{lcccc}
\hline Cultivar & $\alpha_{\mathrm{TF}}$ & $\beta_{\mathrm{T} \Phi}$ & $\gamma_{\mathrm{T \Phi}}$ & $\boldsymbol{\delta}_{\mathrm{TF}}$ \\
\hline $\mathrm{A}$ & $54.83 \pm 6.23$ & $99.15 \pm 11.64$ & $\mathrm{ND}$ & $0.12 \pm 0.02$ \\
$\mathrm{~B}$ & $57.52 \pm 6.87$ & $125.29 \pm 12.62$ & $0.28 \pm 0.03$ & $0.69 \pm 0.09^{*}$ \\
$\mathrm{C}$ & $55.27 \pm 4.88$ & $85.22 \pm 6.12$ & $0.41 \pm 0.06$ & $1.78 \pm 0.15$ \\
$\mathrm{D}$ & $52.43 \pm 3.06$ & $84.57 \pm 5.93$ & $0.31 \pm 0.05^{*}$ & $0.10 \pm 0.02$ \\
E & $79.65 \pm 4.15$ & $79.31 \pm 3.66$ & $0.46 \pm 0.05$ & $1.33 \pm 0.08$ \\
F & $84.76 \pm 5.02$ & $89.27 \pm 4.89$ & $0.77 \pm 0.12$ & $2.13 \pm 0.17$ \\
G & $84.68 \pm 5.61$ & $79.21 \pm 4.25^{*}$ & $4.33 \pm 0.21$ & $7.55 \pm 0.58$ \\
\hline
\end{tabular}

Mean standard deviation $(\mathrm{n}=3)$.

$* P \leq 0.001$.

ND: Not Detected.

TABLE 6. Triglyceride composition (\%) of lipid fractions extracted from apple seed oils

\begin{tabular}{lccccccccc}
\hline Cultivar & LLL & LLO & LLP & OOL & SOL & SOL & OOO & OOP & PPO \\
\hline A & $22.57 \pm 1.18$ & $6.10 \pm 0.58$ & $41.17 \pm 1.98$ & $5.60 \pm 0.35$ & $20.42 \pm 1.38$ & $0.57 \pm 0.07$ & $1.77 \pm 0.23$ & $1.38 \pm 0.26$ & $0.23 \pm 0.08$ \\
B & $27.12 \pm 1.32$ & $7.90 \pm 0.72^{*}$ & $39.79 \pm 1.35$ & $5.75 \pm 0.21^{*}$ & $16.85 \pm 1.29$ & $0.50 \pm 0.08$ & $1.44 \pm 0.13^{*}$ & $0.51 \pm 0.18$ & $0.17 \pm 0.04$ \\
C & $17.80 \pm 1.96$ & $4.49 \pm 0.18^{*}$ & $40.69 \pm 2.04$ & $5.67 \pm 0.06$ & $24.71 \pm 1.86$ & $0.96 \pm 0.08$ & $3.96 \pm 0.15$ & $1.76 \pm 0.04$ & $0.28 \pm 0.03$ \\
D & $23.15 \pm 1.96$ & $7.61 \pm 0.61$ & $39.32 \pm 1.66$ & $6.67 \pm 0.51$ & $19.09 \pm 1.38$ & $0.81 \pm 0.13^{*}$ & $2.04 \pm 0.16$ & $1.18 \pm 0.14$ & $0.22 \pm 0.05$ \\
E & $22.11 \pm 1.64$ & $7.20 \pm 0.49$ & $39.88 \pm 1.47$ & $7.29 \pm 0.38^{*}$ & $19.35 \pm 1.24$ & $0.76 \pm 0.16^{*}$ & $1.98 \pm 0.19$ & $1.09 \pm 0.11$ & $0.31 \pm 0.06$ \\
\hline
\end{tabular}

Mean standard deviation $(\mathrm{n}=3)$.

$* P \leq 0.001$

main constituent in the blanquina species followed by the Collaos species ( $55.55 \pm 2.96 \%$ of the total PL). Phophatidiletanolamine $(30.80 \pm 1.54 \%$ of the total PL) and phophatidilinositol $(31.80 \pm 0.25 \%$ of the total PL) showed a higher value for Limón Montés and Raxao species than the other species. These values were somewhat higher than those obtained by Zlatanov et al. (1997) in a study of the phospholipid composition of Rosaceae seed oil. Table 4 shows the content in sterols in Blanquina, Raxao, Collaos, Durona, Riega, Solarina and Limón Montés apple seed oils. $\beta$-sitosterol was the major sterol in all apple seed varieties. Solarina seed oil was the one with the highest content at $558.52 \pm 9.42 \mathrm{mg} 100 \mathrm{~g}^{-1}$ of oil while Blanquina seed oil was the one that presents the lowest values at $166.55 \pm 1.89 \mathrm{mg} 100 \mathrm{~g} \mathrm{~g}^{-1}$ of oil. Likewise, Limón Montés seeds had the highest content in campesterol at $49.25 \pm 1.16 \mathrm{mg}^{100 \mathrm{~g}^{-1} \text { of }}$ oil and Blanquina the least at $17.70 \pm 0.22 \mathrm{mg} 100 \mathrm{~g}^{-1}$ of oil. The stigmasterol content in Solarina was worth noting at $4.05 \pm 0.37 \mathrm{mg} 100 \mathrm{~g}^{-1}$ of oil. With regard to $\Delta-5$ avenasterol, Solarina seed contained $56.59 \pm 1.94 \mathrm{mg} 100 \mathrm{~g}^{-1}$ of oil, while Blanquina had only $14.37 \pm 0.43 \mathrm{mg} 100 \mathrm{~g}^{-1}$ of oil. Table 5 shows the content in tocopherols in the studied apple seed oils. Raxao presented the highest content in total $\beta$-tocopherol at $125.29 \pm 12.62 \mathrm{mg} \mathrm{Kg}^{-1}$ of oil and Limón Montés seed oil the lowest content at
$79.21 \pm 4.25 \mathrm{mg} \mathrm{Kg}^{-1}$ of oil. $\alpha$-tocopherol was the prominent tocopherol in Limón Montés, with a content of $84.68 \pm 5.61 \mathrm{mg} \mathrm{Kg}{ }^{-1}$ of oil followed by the Solarina species with $84.76 \pm 5.02 \mathrm{mg}^{100 \mathrm{Kg}^{-1}}$ of oil. The main triglyceride composition of apple seeds (Table 6) was made up of LLP $(41.17-39.32 \%$ ) followed by LLL (27.12-17.80\%). The triglycerides present in small amounts were SOL $(0.81-0.50 \%)$ and PPO $(0.31-0.17 \%)$. Triglycerides with three

TABLE 7. Eigenvalues of correlation matrix, and related statistics. Active variables only

\begin{tabular}{lccc}
\hline Compound classes & PC & Eigenvalue & $\begin{array}{c}\% \\
\text { Total-variance }\end{array}$ \\
\hline Fatty acids & 1 & 5.665 & 62.95 \\
& 2 & 1.464 & 16.27 \\
Triacylglycerols & 1 & 5.120 & 56.89 \\
& 2 & 2.058 & 22.88 \\
Phospholipids & 1 & 3.347 & 66.95 \\
& 2 & 1.296 & 25.91 \\
Sterols & 1 & 7.686 & 69.88 \\
& 2 & 1.442 & 13.11 \\
Tocopherols & 1 & 2.171 & 54.27 \\
& 2 & 0.847 & 21.17 \\
\hline
\end{tabular}



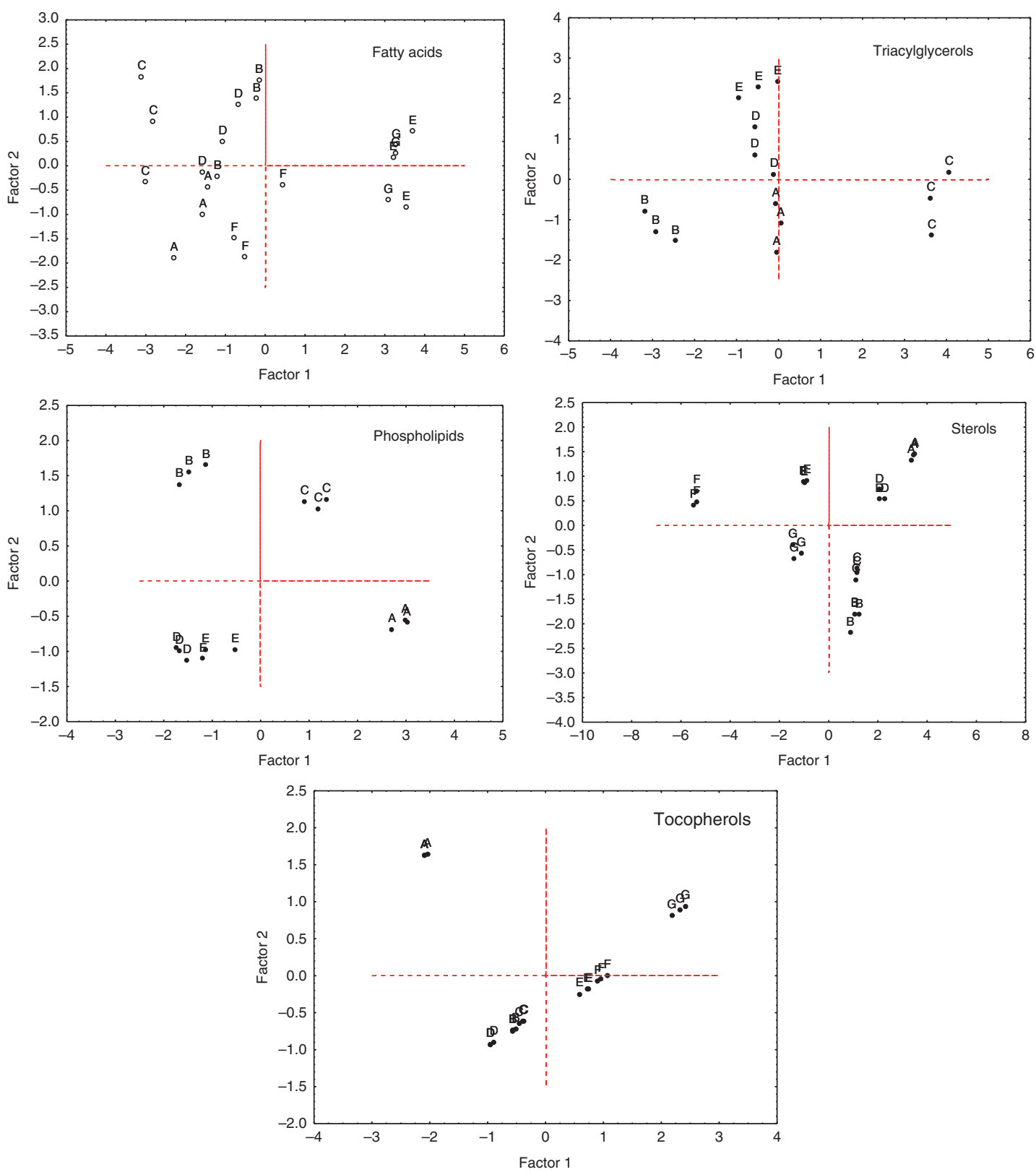

Figure 1. Score plot in the plane of the two first PCs. Letters A, B, C, D, E, F, G, I corresponding to the different compound groups that are gathered in tables 1 to 7 .

unsaturated acids presented the highest proportions, followed by those that have two unsaturated acids.

\subsection{Principal component analysis}

A PCA was applied to the data set to obtain linear combinations of the variables called principal components (PCs). The first principal component (PC1) expresses the largest variability and each successive PC represents as much of the residual variability as possible. The results of this analysis are included in
Table 7. As can be seen, the two first PCs obtained present eigenvalues greater than 1 , the explanation of the original variance for each PC is shown in this table. For fatty acids PC1 is highly influenced by C16:1, C18:0, C18:1, C18:2, C20:0, C20:1 and C22:0. In the case of PC2, the most contributing variable is $\mathrm{C} 18: 3$. In the case of triacylglycerols, $\mathrm{PC} 1$ is highly influenced by LLL, LLO, SOL, SOLn, OOO and OOP. The most contributing variables to $\mathrm{PC} 2$ are OOL and PPO. For phospholipids PC1 is highly influenced by the total content, PC, PE and PI. 

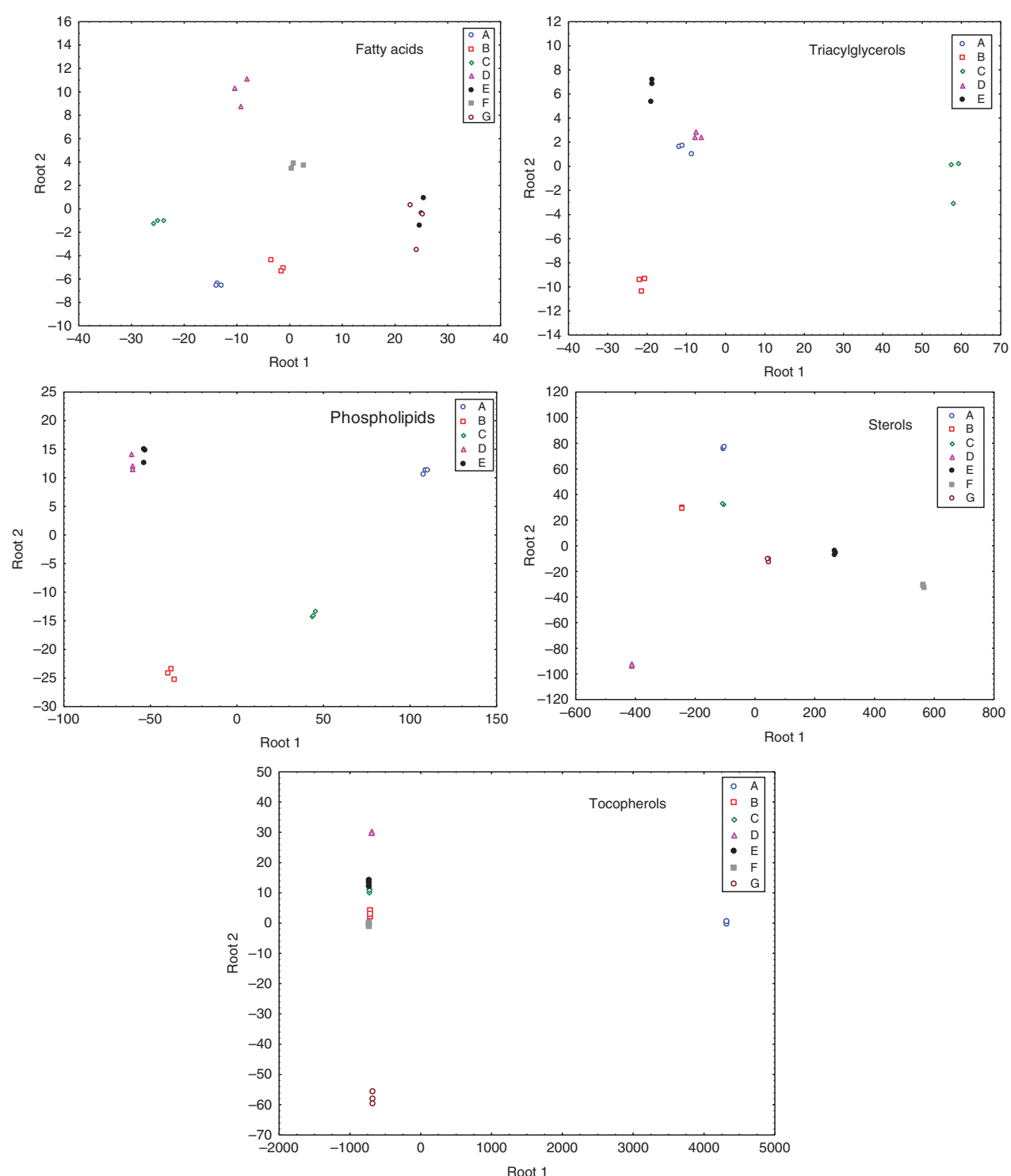

FIGURE 2. Scatterplot of the canonical scores corresponding to different species samples. Letters A, B, C, D, E, F, G, I corresponding to the different compound groups that are gathered in tables 1 to 7 .

The most contributing variable to PC2 is LPC. In the case of unsaponifiable compounds, brasicasterol, campesterol, stigmasterol, sitosterol, sitostanol, avenasterol, stigmastenol, avenasterol, and tocopherol exert a great influence on PC1. The most contributing variables to $\mathrm{PC} 2$ are cholesterol and $\gamma$-tocopherol.

The two-dimensional plots of the PCs can be used to reveal the internal structure of the data and visualize data trends Jolliffe (2002). Figure 1 shows the distribution of the samples in the plane formed by the two first PCs, in this figure a good separation between specie samples can be observed, along with their remarkable distribution of positive or negative values according to the scores of PC1 and PC2. Taking into account these results, linear discriminant analysis was applied to obtain an adequate classification model.

\subsection{Linear discriminant analysis}

The following step in our analysis was to apply the procedures of supervised pattern recognition in order to achieve a better separation. Accordingly, LDA (Coomans, et al., 1979) was applied to the data set to obtain suitable classification rules for the samples. The corresponding discriminant functions were calculated as linear combinations of the chemical descriptors. The criterion used for feature selection was the backward stepwise approach. In a first run, all the variables are present in the model; in each step the variable with least discriminant power, according to the Wilks' 1 statistic test (Gardine, 1997), is rejected. Figure 2 shows the sample distribution in the space of the different 
obtained discriminant functions. The seven oil samples appear completely separated.

\section{CONCLUSIONS}

On the basis of the present study, it may be concluded that the nutritional properties of the studied apple seed oils possess a high added value. The composition in lipids of these seeds presents high contents in polyunsaturated fatty acids C18:2, sterols ( $\beta$-sitosterol), phospholipids (phosphatidilcoline), and tocopherols (alfa-tocopherol). The extraction of these apple seed oils is an option to obtain high added value oils and an additional channel for their use as rich in bioactive nutraceutical compounds to assess the potential use of the oils in foodstuffs. From the point of view of authenticity, it could be a useful tool to know the trazability of apple seed oil with DO compared to others in order to avoide adulteration through the study of the minor oil components.

\section{ACKNOWLEDGMENTS}

This research was conducted with support from the regional Government of the Principado of Asturias (Spain). The authors would like to acknowledge Isabel Cuesta, Ana Hernández and Jorge Alvarez for their technical assistance and the Serida and San Martín de Llanes for the selection of DO apples. The authors also wish to thank Dra. M. Prieto from the University of Oviedo, a group associated with the Spanish Scientific Research Council (CSIC).

\section{REFERENCES}

Alonso L. 1993. Fat modification in Afuega' 1 Pitu cheese during ripening by gas capillary gas chromatography. $\mathrm{J}$. Am. Oil Chem. Soc. 70, 1035-1037. http://dx.doi.org/10.1007/ BF02543033.

Anwar F, Latif S, Ashraf M. 2006. Analytical characterization of hemp (cannabis sativa) seed oil from different agroecological zones of Pakistan. J. Am. Oil Chem. Soc. 83, 323-329. http://dx.doi.org/10.1007/s11746-006-1207-x.

BOE (Spanish Oficial Bolletin). Cicer origen denomination from Asturias. $n^{\circ}$ 38. 5524-5533. 11/2/2003.

Cai YQ, Keiko A, Terutaka K, Hidetoyo T, Minoru K. 2003. The relationship between diet and mortality of cancer and non-communicable disease in Japan. J. Nanjing Med. University 17, 95-111.

Coomans D, Massart, DL, Kaufman L, 1979. Anal. Chim. Acta 112 97-122. http://dx.doi.org/10.1016/S0003-2670(01)83513-3.

Europen Union, Official Diary, reglament $n^{\circ} .479 / 2008$.

Gardine WP. 1997. Statistical analysis methods for chemistry, Royal Society of Chemistry. Cambridge, pp. 313-328.

$\mathrm{Hu}$ F, 2006. Study on the international competitiveness of apple in China. Productivity Res. 10, 17-19.
International Union of Pure and Applied Chemistry (IUPAC). 1987a. Standard Methods for the Analysis of Oils, Fats and Derivatives: Method 1122. Determination of oil content (extraction method). $7^{\mathrm{a}}$ edn. Eds. C. Paquot, A. Haufenne, Blackwell Scientific Publications, Oxford, UK, 1987d, pp. 14-16.

International Union of Pure and Applied Chemistry (IUPAC). 1987b. Standard Methods for the Analysis of Oils, Fats and Derivatives: Method 1121. Determination of moisture

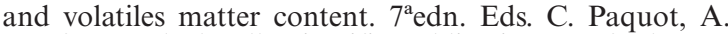
Haufenne. Blackwell Scientific Publications, Oxford, UK, pp. $13-16$.

International Union of Pure and Applied Chemistry (IUPAC). 1987c. Standards Methods for the Analysis of Oils, Fats and Derivatives. Methods 2301. Preparation of the fatty acid methyl esters. $7^{\text {a } e d n . ~ E d s . ~ C . ~ P a q u o t, ~ A . ~ H a u f e n n e . ~}$ Blacwell Scientific Publications, Oxford, UK, pp. 123-129

International Union of Pure and Applied Chemistry (IUPAC). 1987d. Standard Methods for the Analysis of Oils, Fats and Derivatives: Method 2411. Identification and determination of tocopherols. $7^{\mathrm{a} e d n}$. Eds. C. Paquot, A. Haufenne, Blackwell Scientific Publications, Oxford, UK, pp. $174-219$.

Jolliffe I T. 2002. Principal Components Analysis, Second ed., Springer, New York.

Kris-Etherton PM, Etherton TD. 2003. The impact of the changing fatty acid profile on fats on the diet assessment and health. J. Food Comp. Anal. 16, 373-378. http://dx.doi. org/10.1016/S0889-1575(03)00052-8.

Lei Tian H, Zhan P, Li KX. 2010. Analysis of components and study on antioxidant and antimicrobial activities of oil in apple seeds. Int. J. Food Sci. Nutr. 61, 395-403. http:// dx.doi.org/10.3109/09637480903535772.

León-Camacho M, Morales MT. 2000. Gas and liquid chromatography: Methodology applied to olive oil. In: Handbook of olive oil: analysis and properties, Eds. J. L. Harwood, R. Aparicio, Aspen, Gaithersburg, MA (USA), pp. 159-208.

Liang YL, Dai CY, Li B, Shu KX. 2006. Study on extracting technology of total flavone in mustard leaf. Food Res. Develop. 27, 73-75.

Maazouzi C, Masson G, Izquierdo, MS, Pihan JC. 2007. Fatty acid composition of the amphipod Dikerogammarus villous: feedind strategies and trophic links. Comparativee Biochemistry and Physiology-Part A: Molecular \& Integrative physiology, 147, 868-875.

Ohama H, Ikeda H, Moriyama H. 2006. Health foods and foods with health claims in Japan. Toxicology. 17, 73-75.

Official Journal of the Commission of the European Communities. 1991. Regulation N²568/91, L248, September 9.

StatSoft Inc. 1995. Statistica 5.5 for Windows Computer Program Manual, Tulsa, OK. StatSoft, Inc. 1995. 2300 East 14th Street, Tulsa, OK 74104

Stone NJ, Kushner R. 2000. Effects of dietary modification and treatment of obesity: Emphasis on improving vascular outcomes. Med. Clin. N. Am. 84, 95-122. http://dx.doi. org/10.1016/S0025-7125(05)70209-1.

Yu X, Van de Voort FR, Li Z, Yue T. 2007. Proximate composition of the aple seed and characterization of its oil. Int. J. Food Eng. 3, 1-8. http://dx.doi.org/10.2202/1556-3758.1283.

Yukui R, Wenya W, Rashid F, Qing L. 2009. Fatty acids composition of apple and pear seed oils. Int. J. Food Prop. 12, 774-779. http://dx.doi.org/10.1080/10942910802054320.

Zlatanov M, Ivanov S, Antonova G, Kouleva I. 1997. Study of phosphopholipids composition of Rosaceae seed Oil. Rev. Ital. Sost. Grasse, 74, 409-410. 